\title{
Notes on the Notes
}

\section{Anne Lange}

In 1957 when Il dottor Živago was published in Milan it became an iconic novel. Within less than a year it was translated into English by Max Hayward and Manya Harari and its popularity soared in the West. By 1958, when Boris Pasternak was awarded the Nobel Prize for literature, his novel must have been read by many Estonians in exile: a prize for a Russian author who deviated from the Soviet newspeak stood out against the backdrop of the realpolitik façade of the everyday. In early 1959, Ivar Ivask, the later editor-in-chief of World Literature Today, then teaching at St. Olaf's College, Northfield, Minnesota, published in Tulimuld, an Estonian cultural magazine in exile, a lengthy article on Pasternak. Ants Oras, writing to Ivask on August 18, 1959, thanks Ivask for the essay and adds, "Dr. Zhivago mõjus sügavalt, kuigi pisut vähem sügavalt kui ootasin. Kõige paremad on selles siiski värsid!" = 'Dr Zhivago impressed me deeply although a bit less than I had expected. It is the poems that are the best part of it!' (Letters 1997: 100). ${ }^{1}$ On October 3, 1959, he continues on the same subject: "nad on moodsa luule kulminatsiooninähteid. Neis on seda lõpmatuse poole ulatumist, mida praegusel ajal leiab nii vähe. Ja muidugi ka seda läbini-meisterlikkust, mis lõpmatuse püüule alles annab ta täie väärtuse" = "[The poems of Zhivago] are a culmination of modern poetry. There is a reaching for infinity in them that is so rare nowadays. And of course, a perfect mastery that gives their aspirations its full value' (ibid.: 104).

The significance of the poems for the novel has been articulated by Boris Pasternak in his explanation to Olga Carlisle (1960): "the plan of the novel is outlined by the poems accompanying it. This is partly why I chose to publish them alongside the novel. They are there also to give the novel more body, more richness".

On January 3, 1960, Oras sent Ivask some of his translations of the Zhivago poems. He was translating from Russian into English, explaining to Ivask that "prosoodia õpetajana pean siiski sellel alal ka inglise keeles praktiliselt sulge harjutama" = "as a teacher of prosody I have to practice my skills in English as well' (Letters 1997: 143). The translations were still meant to be more than a private exercise. Olga Carlisle (1960), publishing her interview with Boris Pasternak in The Paris Review series, has recorded her opinion, shared by

1 Translations from Estonian into English here and below are by the present writer. 
"many others", that "the translation [of the Zhivago poems] into English did not do justice to [Pasternak's] work". On February 24, 1960, Oras received a letter from David V. Erdman, the editor of the New York Public Library Bulletin, who had read the translations of Oras that had been sent to him by Aleksis Rannit, an Estonian poet who also worked for the New York library. Erdman wrote: "I - we - are delighted with your translations of the Zhivago poems. Indeed, I took a very dim view of them as poetry from what I could make out of the translations in the American edition, and now you persuade me that these are really poems. We would be very pleased to have the whole batch for our Bulletin and to make a special Pasternak issue with these and Rannit's next instalment and the essay which Rannit tells me you are willing to write upon the difficulties of translating Pasternak's verse". ${ }^{2}$ The project never materialized, primarily because Pantheon Press did not grant permission for the publication of new English versions of the poems (Letters 1997: 160). Oras, aware of the obstacle, still continued to translate. He had received positive feedback from Erdman, and also Ivask who had written to him: "Pasternaki Živago-värsse pole keegi veel nii idiomaatselt inglise keeled tõlkind - Teie kujundusil on orgaanilist struktuuri; mõjuvad täiesti inglise originaalidena. [...] Kindlasti olete nende kolme tõlkega midagi suurepärast saavutand ja ma tahaksin kangesti neid autorile endale rõõmuks lähetada!" = 'So far no one has translated Pasternak's Zhivago poems into such idiomatic English. Your solutions have an organic structure; these impress me as English originals. [...] I have no doubt that with these three translations [that is, "The Star of the Nativity", “The Earth", and "Hamlet"] you have achieved something great and I would really like to send them to their author for his delight' (ibid.: 144).

Ivask did send the translations to Pasternak, but whether Pasternak read them or not is not clear from the archives: there is no mention of them in Pasternak's last letter to Ivask dated February 18, 1960; and on May 30, 1960, Boris Pasternak died.

The translations of Oras were redundant. Pasternak was self-sufficient in terms of his resources; he had a good translator in the person of his younger sister Lydia Pasternak Slater, chemist, translator and poet, who lived in Oxford, England. In her 1963 tour of the United States she recalled her brother's telegram comment on her translations: "Translation excellent, at your disposal" (Sheldon 1963). While formulating her task as a translator, Lydia Pasternak has spoken of her belief that the goal of the translator is "to keep the sound of the

2 The letters are now preserved in the Estonian Literary Museum, KM EKLA f. 237, m. 9:23, 1. $4 / 4$. 
original" (ibid.). On the occasion of the new translation of Doctor Zhivago by Richard Pevear and Larissa Volokhonsky decades later, Ann Pasternak Slater (2010) elaborated her mother's view:

Boris's poetry is formally rich, regularly rhymed, and metrically precise. It is full of delectable assonances, at once musical and wholly natural. My mother's first priority was to reproduce his aural effects. She did. This difficult demand inevitably exacted its own price. Her English is flawed - it sounds Russian. But it sings, as Pasternak's poetry does. Its quaintness is authentic.

As Oras in the opening sentence of his comments on translating Pasternak says, his reading was no different. Pasternak's verse is all of a piece; it has its melodic authenticity. The "richness" of the poems that Pasternak himself has referred to in The Paris Review interview is valid on both the formal and the content plane - or the all-of-a-piece-quality would be lost. When commenting on his task as a translator, Oras limits himself to the formal aspects of his craft - the stanza structure, the verbal texture of the poems, the variety of vocabulary registers, and the management of sound - although his explanations, particularly concerning the translation of "The Miracle", leave no doubt that his unit of translation was the text as a whole not its isolated prosodic qualities.

But while aspiring to the unity of his craft, Oras still had second thoughts about its mundane consequences. The translations were of special significance for him, as can be seen in his correspondence with Rannit (preserved in the Beinecke Rare Book and Manuscript Library at Yale). In his letter of May 30, 1963 - that is, three years later - Oras reminds Rannit of his unused Pasternak translations. He admits that his reminder is parmupirin = as boring as a gadfly. But "pärast Pasternaki-tõlgete ilmumist oleks nimelt võib-olla kergem eesti luule tõlkeid avaldada" = 'after the Pasternak translations, it would be easier to publish my translations of Estonian poetry as well', as he had written to Ivask when he began with his work' (Letters 1997: 164). Neither of his translation series - his translations of Pasternak or of Estonian poetry into English - was published in his lifetime. ${ }^{3}$

3 Oras's translations of Estonian poetry have not passed altogether unnoticed. In September 2014, when the US President Barack Obama, on his way to the NATO summit in Wales, stopped at Tallinn to deliver his speech against the backdrop of the escalating military conflict in the Ukraine, he quoted the Estonian poet Marie Under in the translation of Ants Oras. 


\section{References}

Carlisle, Olga 1960 = Boris Pasternak. The Art of Fiction No 25. In: The Paris Review 24. URL: http://www.theparisreview.org/interviews/4679/the-art-of-fiction-no25-boris-pasternak (accessed February 12, 2015).

Ivask, Ivar 1959. Boris Pasternak: revolutsioon ja traditsioon vene kirjanduses [Revolution and Tradition in Russian Literature]. In: Tulimuld 1-2, 60-68, 137-151.

Letters 1997 = Akadeemia kirjades. Ants Orase ja Ivar Ivaski kirjavahetus 1957-1981 [Academy in Letters. Correspondence of Ants Oras and Ivar Ivask 1957-1981]. Compiled by Sirje Olesk. Tartu: Eesti Kirjandusmuuseum.

Pasternak Slater, Ann 2010. Rereading Doctor Zhivago. In: The Guardian, November 6. URL: http://www.theguardian.com/books/2010/nov/06/doctor-zhivago-borispasternak-translation (accessed February 12, 2015).

Sheldon, Richard 1963. The Poetry of Pasternak. The Sister of the Russian Writer Brings Critical Perspective to His Work. In: The Michigan Daily, August 27. 


\section{Hamlet}

The murmurs ebb; on to the stage I enter.

I am trying, standing in the door,

To discover in the distant echoes

What the coming years may hold in store.

The nocturnal darkness with a thousand

Binoculars is focused on to me.

Take away this cup, O Abba, Father,

Everything is possible to thee.

I am fond of this thy stubborn project, And to play my part I am content.

But another drama is in progress,

And, this one, O let me be exempt.

But the plan of action is determined,

And the end irrevocably sealed.

I am alone; all round me drowns in falsehood;

Life is not a walk across a field.

Translated by Lydia Pasternak Slater

from The Michigan Daily August 27, 1963 


\section{Hamlet}

Hum. Then silence. Halting at the door, Gazing far beyond the waiting stage, In the dying echoes from the floor I can hear what happens to my age.

Black binoculars are staring - rather Night's deep dusk in every staring glass Now, if possible, have mercy, Father, Let for once this cup of torment pass.

Yes, I love Thy plan, and none can shake it, I will play my part. But here the play Points another way, so let me take it: This time, Father, let me go my way.

Yet the goal is fixed - the one and only Dark solution that the plot will yield. Pharisees prevail, and I am lonely.

Life is more than passing through a field.

Translated by Ants Oras

from KM EKLA f. 237, m. 37:3, 1. 2, 59 